\title{
Women ANd Poverty - A Human Rights ApProAch
}

\section{SANDRA FREDMAN*}

Despite the global commitment to gender equality in the Millennium Development Goals, women still form the majority of the world's poorest people. This suggests that it is not sufficient to approach the problem of gendered poverty merely as one of development. Instead, attention is increasingly turning to the role of human rights law in addressing this issue. Yet, what can human rights contribute to the complex problem of women in poverty? Equality is universally recognised as a human right. However poverty has not traditionally been regarded as a human rights issue; but instead as a misfortune, analogous to illness, or even as the fault of those living in poverty, whether due to their idleness, misjudgement or lack of talent. Nevertheless, it is argued in this paper that the principle of human rights has much to offer in approaching the question of gendered poverty. At the very least, it signifies that addressing women in poverty is not simply an act of magnanimity on the part of the world's nations. Addressing the specific issue of gendered poverty should be central to States' human rights commitments made both internationally and domestically. And in a world in which power and influence are increasingly wielded by large corporations, such commitments should extend to all who exercise power.

However, it is not sufficient simply to apply existing conceptions of human rights. Instead, it is argued here, human rights need to be "engendered." ${ }^{1}$ This in turn requires an approach to human rights which incorporates the insights of substantive equality. It is not a coincidence that women predominate amongst the poorest in the world: poverty is in many respects a consequence of discrimination against women and gendered inequality. Indeed, in many countries in the world, law significantly contributes to women's poverty and inequality, through express legal limitations and endorsements of cultural or customary discrimination. However, removing such laws to create formal equality before the law is

\footnotetext{
* FBA, QC (hon), Rhodes Professor of Law, Oxford University. I am grateful to Meghan Campbell for her research assistance on this paper.

${ }^{1}$ S. Fredman, Engendering Socio-economic Rights, 25(3) South African Journal of Human Rights (2001)410441 , at 410 .
} 
only the first step. In addition, human rights need to be fashioned to take account of the interlocking factors which operate synergistically to cause and maintain gendered poverty.Even in countries where formal equality before the law has been achieved, women continue to be segregated into low paying jobs and to predominate in precarious employment and the informal sector. To address these issues, it is necessary to recognise the extent to which women's access to economic resources, including waged work, property, and capital for entrepreneurial activities, is a result of structural gender inequalities. Simply giving poor women basic human rights does not necessarily mean that they can enjoy and exercise them; and opening up opportunities in principle does not mean that they are feasible for poor women. In addition, it is necessary to deal with the constraints imposed by a range of other factors, including the power structures within the family; the interaction between the family and the labour market, particularly women's primary responsibility for child-care and housework; violence against women; reproductive rights and age of marriage; and many others.

The aim of this paper is to provide a framework within which human rights and development policies can work together to address the specific ways in which women experience gendered poverty. A human rights approach begins by insisting that women are rights-bearers, not merely beneficiaries. This, in turn, carries with it correlative duties on States and other powerful actors. At the same time, engendered human rights require an understanding of both human rights and their correlative duties which incorporates the insights of substantive equality. Rather than the traditional view of human rights as protections against State intrusion on individual liberty, they should be seen as harnessing State power to facilitate genuine exercise of choice and agency. Engendered human rights aim to take account of the power relations in which rights are exercised. Drawing on the 'capabilities' approach of Amartya Sen and Martha Nussbaum, they aim to enhance the set of feasible options open to women. ${ }^{2}$ At the same time, they are not merely about personal choice. Many aspects of women's lives are based on responsibility, care and interdependence. Thus, engendered human rights should also support the values of interdependence, solidarity and care, whether or not based on choice. ${ }^{3}$ Moreover, engendered human

\footnotetext{
${ }^{2}$ A. Sen, Development as Freedom, OUP, (1999); M. Nussbaum, Women and Human Development, CUP (2000).

${ }^{3}$ See S. Fredman, Human Rights Transformed: Positive Rights and Positive Duties, OUP (2008).
} 
rights are not only about women. They address the gendered relationships in society. For example, measures facilitating women's equal participation in the paid workforce should be matched by measures facilitating men's equal participation in the unpaid work in the home. ${ }^{4}$

The first section of this paper briefly outlines the specific ways in which gender discrimination causes and perpetuates poverty. The second section develops the principles of engendered human rights and creates a framework to assess development policies from the perspective of human rights and substantive equality. The third section applies this analysis to evaluate two popular current policies for dealing with women in poverty: conditional cash transfer programmes (CCTPs) and micro-financing or micro-credit.

\section{GENDERED POVERTY: A HUMAN RIGHTS ISSUE}

The fact that women are disproportionately represented amongst the world's poorest has been frequently underlined. But it is not simply the fact that women are living in poverty that matters. What is of real importance is the gendered nature of that poverty. There are many ways in which gender inequality specifically shapes women's experience of poverty. As a start, in many countries, the continued existence of discriminatory laws actively creates and maintains poverty for women, limiting or obstructing their access to economic resources. In addition, women are not afforded equal protection under the law, as witnessed by the pervasiveness of violence against women, which in turn generates and reinforces women's poverty. Even when women have attained formal equality before the law, structural inequalities persist which restrict women from full participation in the labour force or access to capital assets and entrepreneurship opportunities. Anti-discrimination laws, while important, have only made limited inroads into this problem.

\section{A. Poverty constituted by law}

\footnotetext{
${ }^{4}$ See S. Fredman, Reversing Roles: Bringing Men into the Frame, International Journal of Law in Context (forthcoming).
} 
Although great strides have been made in many countries to provide equality before the law, there are still too many jurisdictions which maintain directly discriminatory laws. ${ }^{5}$ Many of these laws seriously curtail the ability of women to access paid work or property rights, therefore being a direct cause of women's poverty. This is particularly true of laws on marriage, property and inheritance. In many countries, women are still deprived of full legal status on marriage; ${ }^{6}$ and it is commonplace for inheritance laws to discriminate against women. ${ }^{7}$ Customary law, recognised as a source of personal law in a number of countries, frequently provides for patrilineal succession, excluding women from inheritance; ${ }^{8}$ and in a number of countries, such laws are exempt from constitutional equality

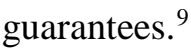

Such laws have a direct impact on women's economic activity and therefore women’s poverty. Absence of property rights means that women are vulnerable to being precipitated into destitution on widowhood or divorce. Women who are subject to early marriage, to treatment as minors under the guardianship of male relatives, to eviction from their property on widowhood, and other legal forms of discrimination, are inevitably highly limited in their ability to undertake paid work, or to benefit from paid work in terms of income, training, career progression or solidarity at work. Without secure rights to education, property, social security or contract, labour market participation is severely compromised: where women can access jobs at all, they are likely to be precarious or on poor terms and conditions. Women lack collateral to take out credit and are therefore seriously constrained in even the most basic of entrepreneurship activities. Women who are not permitted to leave the house or to travel freely are clearly cut off from income earning opportunities. Hence women might be poor even within well off households. Lack of access to independent resources in turn means that they have limited power and

\footnotetext{
${ }^{5}$ World Bank and International Financial Corporation, Women, Business and the Law 2014: Removing Restrictions to Enhance Gender Equality: Key Findings, World Bank(2013) 8.

${ }^{6}$ Botswana, Burundi, Cameroon, Central African Republic, Chad, Comoros, Democratic Republic of Congo, Republic of Congo, Cote d’Ivoire, Gabon, Guniea, Guinea-Bissau, Madagascar, Mali, Mauritania, Niger, Rwanda, Senegal, Somalia, Sudan, Swaziland and Togo.Ibid.

${ }^{7}$ Ibid: for details see Klugman and Twigg in this volume.

${ }^{8}$ See further Masengu in this volume.

${ }^{9}$ M. Hallward-Driemeier and T. Hasan, Empowering Women, Legal Rights and Economic Opportunities in Africa, World Bank (2012).
} 
agency within the family and women who are subject to domestic violence might find it impossible to escape.

Poverty is not only constituted by direct laws; but also indirectly, by lack of proper enforcement of existing laws in relation to women. Although laws against violence and assault exist in all countries, in many countries, these are not used to curb what the World Bank has called the "epidemic of violence" against women. ${ }^{10}$ The scale and prevalence of violence against women are constantly referred to by UN treaty monitoring bodies such as CEDAW and CERD. In the most recent reporting round, the CEDAW committee referred with concern to the scale of violence against women in its concluding observations in relation to the Philippines, Nepal, Bangladesh, Brazil, Nigeria, Botswana, India, South Africa and Zambia, but there are many others. Violence includes domestic violence, rape, acid throwing, dowry related violence, fatwa-instigated violence and sexual harassment at work, with alarming rates of violence against migrant women, Dalit women, and women from ethnic minorities. The threat of rape and sexual assault is a particular problem for women and girls living in urban slums and informal settlements, where lack of access to adequate sanitation facilities exacerbate the risks of sexual violence. $^{11}$

Absence of protection against violence not only deprives women of their right to personal integrity but also functions as a serious obstacle to education, paid employment, entrepreneurship or other ways of alleviating poverty. Poverty and violence interact in a vicious cycle. Women facing sexual harassment at work, violence at home or violence on the streets, are unlikely to be able to participate on equal terms in the paid labour market. Poverty also forces women to carry out daily economic activities which put them at higher risk, such as fetching wood and water, accessing work-places at night, working as domestic workers in other people’s households, or engaging in precarious work generally. Women who lack sufficient economic resources may have to engage in transactional sex, exposing them to heightened levels of violence. ${ }^{12}$

\footnotetext{
${ }^{10}$ World Bank Group, Voice and Agency: Empowering Women and Girls for Shared Prosperity, World Bank(2014) at 55ff.

${ }^{11}$ CEDAW Committee, Concluding Observations: Kenya (2011) CEDAW/C/KEN/CO/7 at para 73.

${ }^{12}$ Fredman and GoldblattSubstantive Equality, UN Women Discussion Paper Series (Forthcoming, January 2015).
} 
Other discriminatory customary and traditional practices are condoned by the law. The CEDAW committee has referred with concern to a number of such practices. These include, in the case of Botswana, widowhood rites and practices, the payment of bogadi (dowry) and privileges in favour of men, such as their customary right to treat their wives in the same way as minor children. ${ }^{13}$ In its concluding observations on Zambia, the Committee refers to harmful practices such as sexual cleansing,,${ }^{14}$ polygamy, bride price (lobola) and property grabbing. ${ }^{15}$ In the case of Nepal, the committee has expressed its concern at harmful traditional practices, such as child marriage, the dowry system, son preference, polygamy, and accusing widows of witchcraft. A particularly harmful practice is that of chaupadi, according to which women and girls are banished from the house during menstruation. Despite a ban being imposed by the Supreme Court on the chaupadi tradition in 2004, the practice remains widespread. Also highly problematic is the practice of deuki, whereby young girls are offered up to the local temple in the hope of gaining protection from the gods. Deukis are often forced into prostitution from a very young age, and because they are deemed impure they have no prospects of marriage or future employment. This practice too has been formally abolished in Nepal, but continues to occur in some areas. ${ }^{16}$ In the case of South Africa, ${ }^{17}$ the CEDAW committee has referred with concern to entrenched harmful cultural norms and practices, including ukuthwala (forced marriages of women and girls to older men through abduction), polygamy and the killing of "witches"; in Nigeria, to widowhood rites, including humiliation, seclusion, and denial of the right to bathe or move around; ${ }^{18}$ and in the case of Kenya, to female genital mutilation (FGM), polygamy, bride price and wife inheritance. $^{19}$

\footnotetext{
${ }^{13}$ CEDAW Committee, Concluding Observations: Botswana (2010) CEDAW/C/BOT/CO/3 at para 23.

${ }^{14}$ A practice whereby a widow is required to have sex with a male relative to 'cleanse' her of her husband's ghost. It was reported in 2009 that the Zambian chiefs had decided to ban practices of sexual cleansing and spouse inheritance: see Abigail Chaponda 'Traditional leaders ban sexual cleansing' Zambian Post (23 November 2009) <http://www.postzambia.com/post-read_article.php?articleId=2263\&page=1>(accessed 13 July 2014).

${ }^{15}$ CEDAW Committee, Concluding Observations: Zambia (2011) CEDAW/C/ZMB/5-6 at para 19.

${ }^{16}$ CEDAW Committee, Concluding Observations: Nepal (2011) CEDAW/C/NPL/4-5 at para 17.

${ }^{17}$ CEDAW Committee, Concluding Observations: South Africa (2011) CEDAW/C/ZAF/4 at para 21.

${ }^{18}$ CEDAW Committee, Concluding Observations: Nigeria (2008) CEDAW/C/NGA/CO/6 at para 32.

${ }^{19}$ Concluding Observations: Kenya, supra note 17 at para 17.
} 


\section{B. Structural Inequality}

The achievement of formal equality before the law is essential to addressing women's poverty. The abolition of expressly discriminatory laws needs to be accompanied by statutory anti-discrimination laws, which bind private individuals as well as the State, especially in the employment context. But the experience of developed countries demonstrates that, even if properly applied, such legislation cannot achieve full equality. Instead, structural inequalities are maintained through cultural and social forces. Despite formal guarantees of equality, women's inequality persists. Nearly four decades of equal pay legislation and sex discrimination law in the UK have not eliminated the gender pay gap. ${ }^{20}$ Women continue to be segregated into lower paying jobs; and women predominate among part-time and precarious workers. This pattern is reflected in many other countries, where high rates of female unemployment, job segregation, low pay, sexual harassment at work and a wide gender gap remain endemic. $^{21}$

Gender continues to shape women's experience of poverty in several ways. Foremost among them is the fact that women remain primarily responsible for childcare, elder-care and housework. At the same time, they are increasingly required to contribute to the income of the household through paid work. This has serious implications for women. Constraints on time and mobility mean that their opportunities in the job market are often limited. ${ }^{22}$ Women's market work is therefore disproportionately concentrated in part-time and precarious work. This has been exacerbated in recent years. With the growing movement towards "flexibilisation" of labour markets throughout the world, many firms are increasingly making use of sub-contracted women home workers at very low wages to replace core full-time workers. ${ }^{23}$ Women also predominate in the informal sector. In sub-Saharan

\footnotetext{
${ }^{20}$ S. Fredman, Reforming Equal Pay Laws, 37(3) Industrial Law Journal (2008) 193 - 218.

${ }^{21}$ S. Fredman, Anti-Discrimination Laws and Work in the Developing World: A Thematic Overview: Background Paper for the World Development Report 2013, World Bank (2013)

$<$ https://openknowledge.worldbank.org/handle/10986/12129>.

${ }^{22}$ Report submitted by the Special Rapporteur on the right to food, Olivier De SchutterWomen's rights and the right to food (2012) A/HRC/22/50, para 2.

${ }^{23}$ ILO, Equality at Work: Tackling the Challenge: Global Report under the Follow-up to the ILO Declaration on Fundamental Principles and Rights at Work (2007).<http://www.ilo.org/global/What_we_do/Publications/Officialdocuments/lang-en/docNameWCMS_082607/index htm>.
} 
Africa, 84 per cent of women non-agricultural workers are informally employed compared to 63 per cent for men, and if informal agricultural work is included, these figures are even higher. ${ }^{24}$ Moreover, the informal economy is segmented by employment status and by sex. The highest-paid segment, microentrepreneurs who hire others, is predominantly male, while women are over-represented in the lowestpaid segment of the informal economy - as home workers or industrial outworkers. ${ }^{25}$ Alternatively, many women are required to make a stark choice and leave their homes to work in other people’s houses as domestic workers or even to migrate to other countries to find work. In the Philippines, one of the major sources of GDP takes the form of remittances from women working as domestic workers abroad. ${ }^{26}$ Women's continuing primary responsibility for home work and childcare also affects the value attached to women's market work. Because domestic work and childcare are done for free at home, much of women's paid work of a similar type is seriously undervalued. This includes catering, cleaning, caring work, and agricultural work. ${ }^{27}$

Thus while paid work can bring with it a modicum of agency and independence, women are often in a position where they have no option but to accept precarious and exploitative working conditions and pay. With no economic value given to unpaid activities, women's contribution remains invisible, ${ }^{28}$ as does their role in facilitating men's ability to access work. ${ }^{29}$ This affects not just their actual income but also their ability to act as equal partners in most economic transactions such as purchasing property or their ability to offer collateral for bank loans. Moreover, because women are for the most part engaged in low-paid work in the small-scale retail sector, informal sector or small farming, they are particularly vulnerable to economic downturns, public spending cuts and privatisation of public

\footnotetext{
${ }^{24}$ WIEGO (Women in Informal Employment Globalizing and Organizing), Women and Men in Informal Employment: Key Facts and New MD3

Indicator<<http://wiego.org/sites/wiego.org/files/resources/files/Women-Men-in-Informal-Employment.pdf > ${ }^{25}$ Ibid.

${ }^{26}$ See S. Fredman, Home from Home: Migrant Domestic Workers and the ILO Convention on Domestic Workers in C. Costello and M. Freedland (ed) Migrants at Work, OUP (2014).

${ }^{27}$ F. Bettio \& A. Verashchagina, Gender Segregation in the Labour Market: Root Causes, Implications and Policy Responses in the EU, European Commission (2009).

${ }^{28}$ United Nations Development Programme, Gender and Human Development, (1995)<http://hdr.undp.org/en/content/human-development-report-1995> at 93.

${ }^{29}$ Ibid. at 97. Gender and Human Development estimates that if the value of unpaid work performed by women and men were seen as market transactions at prevailing wages, the value of underpayment of women's work would be a further 70 per cent or \$16 trillion dollars would be added on to the officially estimated \$23 million of global output. This figure demonstrates the extent of undervaluation of women’s contribution: Ibid. at 97.
} 
utilities such as water and electricity. ${ }^{30}$ Yet poverty reduction strategies take little or no account of the fact that socially essential subsistence, reproductive, and community work performed predominantly by women are not market-oriented. ${ }^{31}$

The fact that the traditional household division of labour has remained intact despite women's increased participation in paid work means that women work longer hours than men in nearly every country, ${ }^{32}$ and a significantly larger proportion of their working time is spent on unpaid activities than that of men. ${ }^{33}$ As a recent study put it: "Instead of replacing time in reproductive work with time in paid work, and shifting compensating amounts of reproductive work to men, it has been found that women tend to increase their total work time". ${ }^{34}$

Particularly important is the impact of gender on the power to control important decisions in one’s life. As Sweetman put it, poverty is ‘as much about agency compromised by abuse, stress, fatigue and voicelessness as it is about lack of resources' ${ }^{35}$ Although this lack of agency is also felt by poor men, gender continues to have a specific impact on women's ability to exercise power to access resources. For example, as Chant notes, household income may bear no relation to women's poverty because women may not be able to access it: "Feminist research has shown that inequitable resource allocation can often lead to 'secondary' poverty among women and children in male-headed households, and, as such, for many women the capacity to command and allocate resources may be

\footnotetext{
${ }^{30}$ B. Rodenberg, Gender and Poverty Reduction: New Conceptual Approaches in International Development Cooperation, Reports and Working Papers 4/2004 Development Institute (2004) at V.

${ }^{31}$ Ibid.

${ }^{32}$ Gender and Human Development, supra note 28 at 6 reported in 1995 that women carry 53 per cent of the burden of work (including both paid and unpaid) in developed countries and 51 per cent in developing countries. See also M.S. Floro and M. Meurs, Global Trends in Women's Access to "Decent Work" (Occasional Paper No. 43) ILO (2009); UNDP, Human Development Report

2007/8<hdr.undp.org/en/media/HDR_20072008_EN_Indicator_tables.pdf $>$ at (Table 32) 342 (accessed 14 July 2014).

${ }^{33}$ Of men's total work time in industrial countries, roughly two-thirds is spent on paid activities and one-third on unpaid, while the converse is true for women. In developing countries, more than three-quarters of men's work takes place in market activities. Gender and Human Development, supra note 28 at 6 . For more recent figures for see European Commission 'Report on Equality Between Men and Women 2015' (EU 2016) p.10; OECD Development Centre, document 'Unpaid Care Work: The missing link in the analysis of gender gaps in labour outcomes' (Dec 2014), p.2

${ }^{34}$ M.S. Floro and M. Meurs, supra note 32 at 6.

${ }^{35}$ C. Sweetman, Editorial in C. Sweetman (ed), Gender and the Millennium Development Goals, Oxfam (2005) at 3 .
} 
more important than the actual resource base in their households.” 36 This is true too for access to information and information technology. ${ }^{37}$

\section{ENGENDERING HUMAN RIGHTS}

Poverty has not traditionally been considered to be a human rights issue. Whereas the paradigmatic understanding of the role of human rights is to function as a protection against intrusion by the State into individual liberty, the State is not regarded as the cause of poverty. Instead poverty is characterised as a misfortune, analogous to illness, or even as the fault of those living in poverty, whether due to their idleness, misjudgement or lack of talent. Hence poverty has been considered a matter of charity, development policies or the welfare State. This understanding of both poverty and human rights has, however, been increasingly challenged. Instead, there is a growing acceptance that poverty is systemic. Moreover, from a human rights perspective, it is difficult to see why freedom should be seen only as an absence of deliberate State interference. ${ }^{38}$ If human rights are to be secured to all, it does not make sense to ignore other constraints on the ability of individuals to exercise their rights. Such constraints can arise as much from poverty, poor health, and lack of education as from tyranny and intolerance. This approach draws on the insights of modern theorists, in particular of Amartya Sen, who see freedom not as absence of coercion, but as agency, or the ability to exercise genuine choice and act on those choices. For Sen, freedom consists in being able to do and be what one has reason to value. As Sen argues: "What people can achieve is influenced by economic opportunities, political liberties, social powers and the enabling conditions of good health, basic education, and the encouragement and cultivation of initiatives." ${ }^{39}$ Far from being irrelevant, the ability to achieve one's valued goals is essential to this conception of freedom. This necessitates the "removal of major sources of un-freedom: poverty as well

\footnotetext{
${ }^{36}$ S. Chant, Rethinking the Feminisation of Poverty, 7(2) Journal of Development and Capabilities (2006) 201220 at 2005.

${ }^{37}$ L.Scott, Thinking Critically About Women’s Entrepreneurship in Developing Countries, <http://www.sbs.ox.ac.uk/ideas-impact/skoll/knowledge-generation/applied-research/oxfordimpact/impact-essays> accessed 14 July 2014.

${ }^{38}$ S. Fredman, supra note 3 at chap 1.

${ }^{39} \mathrm{~A}$. Sen, supra note 2 at 5.
} 
as tyranny, poor economic opportunities as well as systematic social deprivation, neglect of public facilities as well as intolerance or over-activity of repressive states." ${ }^{40}$

This approach is strengthened by the recognition that the distinction between non-intervention and positive action is itself elusive. Poverty is always capable of being construed as an act of deliberate intervention by the State: it is the legal regime which creates property rights and protects them from theft and invasion. Bentham famously declared: "Property is entirely the creature of law ... It is from the law alone that I can enclose a field and give myself to its cultivation ... Before the law, there was no property; take away the laws, all property ceases.”41 Therefore, as Sunstein argues, if homeless people lack a place to live, it is because the rules of property are enforced. Similarly, there is no law against eating in the abstract; it is the law which forbids a hungry person to eat any of the food which exists in the community. ${ }^{42}$ Sen puts it even more strongly. People are hungry if they lack entitlements that enable them to eat; thus, "the law stands between food availability and food entitlement. Starvation deaths can reflect legality with a vengeance.” ${ }^{23}$ Thus, whether poverty is construed as deliberate State intervention, or as an obstacle to freedom which the State has the means to remove, it remains true to say that positive action is required from the State in order to ensure that an individual can exercise her human rights. It is now widely accepted that the State has the duty not just to refrain from interfering in rights, but also to protect individuals against interference with their rights by others and to promote and fulfil basic human rights.

The claim that gendered poverty is a human rights issue is particularly powerful, given the widespread recognition of a right to equality and non-discrimination on grounds of gender. The Universal Declaration of Human Rights proclaims in its preamble that both freedom from fear and freedom from want are "the highest aspiration of the common people.” This is reiterated in identically worded phrases in the preambles of both the International Covenant of Civil and Political Rights (ICCPR) and the International Covenant of Economic, Social and Cultural Rights (ICESCR), which

\footnotetext{
${ }^{40}$ Ibid. at 3 .

${ }^{41}$ J. Bentham, Principles of the Civil Code, Simkin, Marshall (1898) at 1:307-308.

${ }^{42}$ C. R. Sunstein, The Second Bill of Rights, Basic Books (2004) at 23-24.

${ }^{43} \mathrm{~A}$. Sen,supra note 2 at $165-166$.
} 
state: "Recognizing that, in accordance with the Universal Declaration of Human Rights, the ideal of free human beings enjoying civil and political freedom and freedom from fear and want can only be achieved if conditions are created whereby everyone may enjoy his civil and political rights, as well as his economic, social and cultural rights.” Similarly, the preamble the Convention on the Elimination of Discrimination against Women (CEDAW) expresses the concern that "in situations of poverty women have the least access to food, health, education, training and opportunities for employment and other needs." ${ }^{44}$

This, however, is only the first step. More complex is to determine how human rights can address the distinctive nature of women in poverty. As we have seen above, it is because of deep-seated structural inequality that poor women are unable to access or enjoy their basic human rights. An engendered human rights approach aims to take account of the power relations in which rights are exercised. The fact that the law states that everyone, including women, are the subject of human rights does not necessarily mean that poor women can exercise them. In addition, it is necessary to deal with the many constraints elaborated above. Moreover, engendered human rights are not only about women. They address the gendered relationships in society. The State has the duty not just to restrain its own breaches of human rights, but also to protect women against breaches by others and to promote and fulfil rights through positive action. This analysis can be applied to core civil and political rights as well as socio-economic rights. Thus women's basic right to life in Article 6 ICCPR cannot be exercised so long as the State does not deal effectively with violence against women. The same is true in relation to the shockingly high prevalence of maternal mortality. Similarly, the right in Article 12 to free movement within a country is interfered with by the many religious norms which restrict women's movement.

The need to address the constraints on poor women's ability to exercise their rights is more complex in relation to the duty to promote and fulfil. This can be seen in relation to the right to education. It is now well recognised that improving girls' access to education will significantly facilitate their exit from poverty. Indeed, education was the key indicator chosen to measure the extent to which the commitment to equality for women in MDG3 was realised. The disappointing outcomes of that

\footnotetext{
${ }^{44} 1249$ UNTS 13 (entered into force 3 September 1981).
} 
process demonstrate that the right to education will not be effective unless the right can be used to address the interlocking barriers faced by girls and women. Protection against violence is crucial. Female learners are frequently subject to violent attack on the way to school, in the toilets and elsewhere. In some cases, in countries like Pakistan and Afghanistan, these are deliberately aimed at preventing girls from going to school. Early marriage and teenage pregnancy are particularly serious obstacles to girls' continued education. Reproductive rights are therefore a crucial part of the picture. One example is the widespread practice of expelling pregnant girls and child mothers. ${ }^{45}$ The importance of recognising this as a human rights issue was demonstrated in a recent case before the South African Constitutional court, which was concerned with pregnancy policies adopted by schools in South Africa that provided for the automatic exclusion of any learner from school in the event of her falling pregnant. The court held that the policies differentiated between learners on ground of pregnancy and therefore constituted unfair discrimination in breach of the constitution. ${ }^{46}$ They also limited pregnant learners' fundamental right to basic education and their rights to human dignity, privacy, and bodily and psychological integrity by obliging them to report to the school authorities when they believe they are pregnant. ${ }^{47}$ Similarly, menstruating girls who cannot afford sanitary towels may not go to school if there are no latrines or access to water. ${ }^{48}$ Nor will they go to school if their parents regard it as more costbeneficial for them to do domestic work at home. This is particularly so if educated girls land up being more expensive to parents because larger dowries or lower bride price attaches to them. ${ }^{49}$ More generally, the benefits of education may be curtailed if other social structures are not changed. "What girls can do with their education determines the attractiveness of schooling. If women cannot be employed or self-employed, own land, open a bank account, get a bank loan, if they are denied freedom to marry or not to marry, if they are deprived of political representation, education alone will have little effect on their plight”. ${ }^{50}$

\footnotetext{
${ }^{45} \mathrm{~K}$. Tomasevski, Rights-based Education as Pathway to Gender Equality in I Boerefijn and et al. (eds), Temporary Special Measures, Intersentia (2003) 163-166.

${ }^{46}$ Head of Department, Department of Education, Free State Province v Welkom High School [2013] ZACC 25

(South African Constitutional Court) para 113.

${ }^{47}$ Ibid. at para $114-5$

${ }^{48}$ E. Unterhalter, Gender, Schooling and Global Social Justice, Routledge (2007).

${ }^{49} \mathrm{~K}$. Tomasevski, supranote 53 at 155.

${ }^{50}$ Ibid.
} 
Rights to non-discrimination in the workforce need to be similarly contextualised. Women's disadvantage in the waged labour force reflects not just prejudice in the workforce itself, but also their unequal access to power and resources more generally, whether in the family, in education, in health, in access to property, or personal security. Legal intervention, to be effective, should be capable of addressing the interaction between these factors. This requires a holistic human rights framework, where the right to substantive gender equality infuses both the familiar canon of civil and political rights and the equally important socio-economic rights.Particularly important in redefining the interface between paid work, unpaid work and childcare is the way in which rights to maternity leave, parental leave and childcare are structured. An International Labour Organization (ILO) review of maternity protection in 2004 showed that 167 countries had some legislation in place. However, it is still rare to have paternity or parental leave. The availability of subsidised childcare is again crucial to women's ability to balance paid and unpaid work, but close attention needs to be paid to the way in which it is set up. In particular, the vast majority of childcare workers may themselves be low paid women.

\section{SUBSTANTIVE EQUALITY AND ENGENDERING HUMAN RIGHTS}

Traditionally, equality has been understood in formal terms, requiring simply that likes be treated alike. In US terms, this traditional understanding is known as the "anti-classification" principle, which requires individuals to be treated on their own merit, regardless of their race, or other equivalent characteristics. Formal equality has been of central importance for women, particularly in achieving equality before the law, whether in terms of equal suffrage, equal right to own property or other similar limitations. As we have seen, in many countries, formal equality is yet to be achieved. However, even when women are equal before the law, they lag considerably behind in many respects, particularly in social and economic terms. This has highlighted the weaknesses in a concept of equality which focuses only on treating likes alike. Equal treatment, in the context of considerable antecedent disadvantage, might simply entrench that disadvantage. Moreover, equal treatment is agnostic as to the level of 
treatment: the principle is fulfilled whether all are treated equally well or equally badly. Ultimately, it is not so much the fact of the difference in treatment on grounds of sex that should be at issue, but that a woman is subjected to disadvantage on grounds of her sex.

It was to address these limitations of the principle that likes should be treated alike that substantive equality was developed. ${ }^{51}$ To do so, substantive equality should have at least four features. Firstly, it should be asymmetric. That is, it should distinguish between different treatment that causes further detriment to a disadvantaged group, and different treatment which aims to redress past disadvantage and therefore improve the position of a disadvantaged group. Secondly, it should move away from the assumption of conformity to a male norm. Instead, it should accommodate difference and change existing structures. Thirdly, it should insist on levelling up rather than down. Fourthly, it should entail a positive responsibility to bring about change, regardless of whether individual culpability or violation has been established. Several different concepts have been used to address these challenges, such as equality of results, equality of opportunity and dignity. All of these have their advantages and limitations. Drawing on the strengths of all leads to a four-dimensional approach to equality. ${ }^{52}$

Firstly, substantive equality should concentrate on remedying disadvantage, rather than achieving gender neutrality. Disadvantage is both material and social. Substantive equality aims to redress disadvantage in its specifically gendered context, including women's subordinate position in the family and reproduction, in the paid workforce, and in other relationships of power. The focus on redressing disadvantage has two important implications. Firstly, it is incompatible with a "levelling down" solution. Only if the position of those who are worse off is raised to that of the better off can equality in this sense be satisfied. Secondly, substantive equality contemplates different treatment in order to redress disadvantage. This means that affirmative action measures in favour of women do not breach the principle of equality as long as their aim is to redress discriminatory disadvantage.

The second dimension of substantive inequality aims to redress stigma, stereotyping, humiliation, and violence on grounds of gender. This dimension of substantive equality is best

\footnotetext{
${ }^{51}$ This section is taken from S. Fredman, Discrimination Law, $2^{\text {nd }}$ ed. OUP (2011).

52 See S. Fredman, The Future of Equality in Great Britain, (2002) Working Paper No. 5, Equal Opportunities Commission, Manchester at 25-33.
} 
understood in terms of what Nancy Fraser calls “recognition” wrongs. The concept of "recognition” is based on the Hegelian notion that our identity is constructed (at least partially) in terms of the ways in which others regard us. "Recognition” wrongs consist in "misrecognition” or inequality in the mutual respect and concern that people feel for one another in society. ${ }^{53}$ Such wrongs can be experienced regardless of relative socio-economic disadvantage and distributive wrongs.

The third dimension of substantive equality entails recognition of the ways in which the structures of society entrench women's disadvantage. Instead of requiring women to conform to male norms, substantive equality requires transformation of existing male-oriented institutions and social structures. With this comes the imperative to transcend the public-private divide, recognising the ways in which imbalances in power in the family can reinforce power imbalances in the public sphere and vice versa. In particular, child-care and parenting need to be recognised as a shared social responsibility, and working patterns need to be changed to accommodate this. Substantive equality also requires the accommodation of differences between women.

The final dimension of substantive equality is the importance it attaches to women's agency and voice. As has been recognised in several jurisdictions, equality should specifically compensate for the absence of political power of groups "to whose needs and wishes elected officials have no apparent interest in attending." 54 Substantive equality requires decision-makers to hear and respond to the voices of women, rather than imposing top-down decisions. The challenges of giving women voice cannot be underestimated. Articulating women's interests from a gendered perspective requires closer attention to the diversity of women's voices, to the possible disjuncture between those who speak and those who are affected, and to the need to ensure that the least vocal are nevertheless heard. Moreover, as much as women's voices should be heard in engendering social and economic rights, so social and economic rights are necessary to give women the capability of articulating their perspectives.

One of the key advantages of a multi-dimensional approach is that it provides a framework within which to address the interaction between dimensions. The idea of the four-dimensional structure

\footnotetext{
${ }^{53}$ N. Fraser, Social Justice in the Age of Identity Politics, in N. Fraser and A. Honneth (eds) Redistribution or Recognition? A Philosophical Political Exchange, Verso (2003) at 29.

${ }^{54}$ J.H. Ely, Democracy and Distrust: A Theory of Judicial Review, HUP (1980) at 46.
} 
is to draw explicit attention to all four dimensions in evaluating positions or programmes. Rather than viewing one as a trump over the others, the dimensions should mediate each other, leading to a synthesis or more nuanced response. For example, measures aimed at redistribution can themselves cause recognition harms, such as the stigma experienced by welfare beneficiaries. Affirmative action measures are similarly said to be associated with increased stigma. The four dimensional approach makes it possible to address these tensions. Given that equality aims to redress disadvantage as well as to address stigma, it is crucial to design both welfare and affirmative action measures in ways that advance dignity as well as redistribution. On the other hand, simply addressing recognition harms without paying serious attention to structural change, such as improving the quality of educational provision, is unlikely to achieve substantive equality. Similarly, the multi-dimensional approach precludes the argument that measures increasing disadvantage do not breach equality because they have no impact on the dignity of the claimant. ${ }^{55}$ The participatory dimension also needs to be considered together with other dimensions. While voice is important, it is not necessarily an end in itself, if those women who speak have the effect of worsening other women's disadvantage or perpetuating stigma, prejudice or violence. As an extreme example, the fact that some women perpetuate harmful practices such as female genital mutilation or breast ironing does not in itself justify the devastating effects on women.

\section{EVALUATING DEVELOPMENT POLICIES: A HUMAN RIGHTS APPROACH}

It has been argued above that a human rights approach requires development policies to take into account the insights of substantive equality. The fundamental right to equality is not just a right to formal equality or equal treatment. It is also a right to substantive equality. In this section, the fourdimensional framework is applied to evaluate two increasingly popular types of policies aimed at addressing poverty: conditional cash transfers programmes (CCTPs) and micro-financing schemes. These two examples are chosen because they signify the shift in development policies towards regarding

\footnotetext{
${ }^{55}$ Gosselin v Quebec,2002 SCC 84 (Supreme Court of Canada). See now R v Kapp, 2008 SCC 41 (Supreme Court of Canada).
} 
women as the main vehicle for poverty alleviation. Because recent evidence shows that women are likely to prioritise their children's welfare in using available resources, they are now seen as the main recipients of welfare rights and private financing initiatives. By scrutinising such policies in the light of a substantive equality framework, it is possible to point to ways in which they nevertheless might perpetuate or even aggravate gendered poverty by breaching women's fundamental rights to equality. This does not necessarily mean they should be scrapped. What it does mean is they need to be adjusted to ensure that the women's equality and rights, in the sense understood here, are not breached.

\section{A. Conditional Cash Transfer Programmes}

Conditional cash transfer programmes (CCTPs) have become increasingly popular in many countries. ${ }^{56}$ The World Bank describes such programmes enthusiastically as increasing women's bargaining power and agency, and as reinforcing women's independence within the family. ${ }^{57} \mathrm{CCTPs}$ specifically target women as recipients of benefits, based on research which shows that women tend to use all their income to improve the situation of the household while men often withhold income from the household for personal consumption. ${ }^{58}$ However, correspondingly, it is women who are regarded as responsible for delivering the conditions attached to the transfers, such as taking children for regular health checks, meeting targets for ensuring their children's attendance at school, attending workshops on health and programme coordinators' meetings, and in some cases, contributing a fixed amount of hours of their own work, such as cleaning buildings. ${ }^{59}$ Failure to comply can lead to recipients being struck off the programme. ${ }^{60}$

Evaluating these programmes from the perspective of the four dimensional framework of substantive equality requires specific attention being paid to (i) whether they redress women's gendered

\footnotetext{
${ }^{56}$ A Fiszbein, N. Schady and et al. Conditional Cash Transfers: Reducing Present and Future Poverty, The World Bank (2009) at 4.

${ }^{57}$ Ibid. at $9-10$.

${ }^{58}$ Ibid. at 59.

${ }^{59}$ S. Bradshaw, From Structural Adjustment to Social Adjustment: A Gendered Analysis of Conditional Cash Transfer Programmes in Mexico and Nicaragua, 8(2) Global Social Policy (2008) 188-207 at 191.

${ }^{60}$ M. Molyneux, Mothers at the Service of the New Poverty Agenda: Progresa/Oportunidades, Mexico’s

Conditional Transfer Programme, 40 Social Policy and Administration (2006) 425 - 449 at 434.
} 
disadvantage, (ii) how they address stigma, prejudice, stereotyping and violence, (iii) whether they work towards changing or transforming structures, and (iv) how much voice they give women. Each specific programme has its own characteristics and needs to be evaluated individually. The following gives an illustration of how the four-dimensional framework casts light on the ways in which such policies need to be adjusted if they are to fulfil women's fundamental right to equality.

\section{Redressing disadvantage}

On the face of it, cash transfers given to women can contribute to redressing disadvantage, dependent of course on the value of the transfer. Evaluating programmes from this perspective, however, requires us to examine not just generalised distributive gains, but also the particular redistributive issues which affect women, such as the distribution of power within the family and the distribution of time. ${ }^{61}$ As we have seen, disadvantage in the specific gender sense includes not just lack of access to resources, but as the World Bank Report argues that "attaching strings to the transfers by mandating specific human capital investments could strengthen the mother's bargaining position and reinforce her ability to shift household spending and time allocation decisions.” ${ }^{2}$ However, there is also evidence suggesting that if women bring more resources into the family, men withhold more of their own resources for personal consumption. ${ }^{63}$ Similarly, CCTPs might worsen time poverty: given that women already tend to work more hours than men, particularly in respect of unpaid work. ${ }^{64}$ Research into the Mexican CCTP programme Oportunidades has shown that participating in the programme carries with it a high time burden, and that compulsory attendance criteria are problematic for women engaged in income generating activities. ${ }^{65}$

Moreover, the imposition of conditions is by its nature disempowering. More fundamentally, it is doubtful whether conditionality can ever be regarded as compatible with human rights. The rights-

\footnotetext{
${ }^{61}$ S.Fredman, supra note 51 at 27

${ }^{62}$ A. Fiszbein, N. Schady and et al., supra note 65 at 59.

${ }^{63}$ S. Bradshaw, supra note 69 at 200.

${ }^{64}$ S. Chant, supra note 44 at 179, citing B. Rodenberg, supra note 38 at 17.

${ }^{65}$ S. Bradshaw, supra note 69 at 192.
} 
bearer should not have to behave in a prescribed manner in order to "earn" the right. If failure to send your child to school is regarded as a breach of the law, then criminal penalties should be evenly imposed on all wrongdoers, not just the poor. Conditional cash transfers transform welfare from a right to a reward. Instead, a gendered approach would regard the removal of benefits from the very poorest in society as a breach of the basic human right to welfare. ${ }^{66}$

In addition, reasons for non-compliance may lie deep in the very structure of disadvantage programs are aiming to address. As the Special Rapporteur on extreme poverty and human rights points out, girls might not go to school, leading to a breach of the condition, because they are sexually harassed; pregnant women may fail to fulfil the conditions of attending health clinics because the service is so poor or clinics are so far away. ${ }^{67}$ This is particularly true where conditions attach to women who are heads of their households. She concludes that if conditions are to be imposed, there should be a mechanism in place to help those who are not able to comply ${ }^{68}$

Indeed, research seems to suggest that if empowerment of women is indeed the aim, it is far better achieved by giving resources to women without conditions. Thus, research by Patel et al. into the unconditional Child Support Grant in South Africa found that giving women resources enhanced women's power and control over household decision-making in financial matters, and general household spending in child well being. ${ }^{69}$ Similarly, a study in Malawi showed that girls who received unconditional cash transfers of the same monetary value had similar health and schooling outcomes as those receiving conditional transfers. ${ }^{70}$ Indeed, it is quite likely that conditions are in fact unnecessary:

\footnotetext{
${ }^{66}$ G Standing, 'Behavioural conditionality: why the nudges must be stopped - an opinion piece’ ' [2011] 19 Journal of Poverty and Social Justice 27; M Sepúlveda, Independent Expert on the Question of Human Rights and Extreme Poverty, 'Promotion and Protection of all Human Rights, Civil, Political, Economic, Social and Cultural Rights, Including the Right to Development'(UN Doc A/HRC/11/9, United Nations, General Assembly, 27 March 2009)

${ }^{67}$ Sepúlveda, supra note 66 at para 59.

${ }^{68}$ Ibid.

${ }^{69}$ L Patel and et al, The Gender Dynamics and Impact of the Child Support Grant in Doornkop, Soweto, Centre for Social Development in Africa, University of Johannesburg (2012).

${ }^{70} \mathrm{~L}$ Aber and LB Rawlings, 'North-South Knowledge Sharing on Incentive-Based Conditional Cash Transfer Programs' (SP Discussion Paper No. 1101, Social Protection and Labour, The World Bank, January 2011), at 11, citing S. Baird, C. McIntosh, C and B. Ozler, Cash or Condition? Evidence from a Randomized Cash
} 
women, given the appropriate capability set (such as good quality health clinics situated nearby) would make the best decisions for their children without the need for a condition. ${ }^{71}$

\section{Addressing stigma, prejudice, stereotyping and violence}

At one level, these new approaches to the right to social security represent a welcome advance beyond the view that welfare recipients are passive beneficiaries of charity or of the largesse of the wealthy in society. Instead of the stigmatic portrayal of welfare recipients as parasites or scroungers, the aim is to empower individuals, to enhance their capabilities to find their own way out of poverty, and to recognise their agency. Nevertheless, CCTPs score badly on this aspect of the substantive gender equality framework. CCTPs not only assume but also reinforce women's primary role in child-care. Molyneux reiterates this point: "With fathers marginal to childcare and further marginalised by the design of the programme, the state plays an active role in re-traditionalising gender roles and identities." ${ }^{72}$ Thus fathers of children are left without responsibility for facilitating the education and health care for their children.

This comes together with the assumption that without the conditions, women would not take the specified actions. As described by the World Bank, the aim of CCTPs is to target families who are under-investing in the human capital of their children. One reason why they are under-investing, on this view, is “imperfect altruism." The assumption that women's behaviour needs to be modified if they are not sufficiently altruistic is highly problematic. As Bradshaw points out in relation to the Nicaraguan programme: “The [programme] implicitly suggests that those women targeted need to learn to be better mothers, since transfers are dependent on their attending sessions focussed on better child care and family hygiene, as well as sessions on family planning."73

A further stigmatic aspect of CCTPs concerns the ways in which the conditionality is enforced. A gender-based evaluation needs to consider the extent to which it is stigmatic and intrusive for the

\footnotetext{
Transfer Program, Policy Research Working Paper 5259, The World Bank Development Research Group: Poverty and Inequality Team (March 2010).

${ }^{71}$ S. Bradshaw, supra note 69 at 198.

${ }^{72}$ M. Molyneux, supra note 70 at 440.

${ }^{73}$ Ibid. at 199.
} 
State to monitor women's behaviour sufficiently closely to determine whether they have met the conditions. Standing points out that in Brazil, 17, 000 families qualifying for the Brazilian Bolsa Família“are stripped of entitlement each month because a local official decides that they have acted incorrectly." 74 There is little due process, and any rights of appeal are unlikely to be easily accessed or used. This increases the stigmatic nature of CCTPs. Welfare beneficiaries are rapidly transformed from rights holders to wrongdoers, and worse still, face sanctions without the usual due process afforded to other forms of wrongdoing, least of all those faced by the well off in society, whose tax avoidance is scarcely regarded as culpable. This also creates incentives towards corruption by those with power to provide the records (such as school attendance registers) necessary to fulfil the incentives. ${ }^{75}$

3.Transforming social structures and accommodating difference

On the face of it, CCTPs aim to break the cycle of inter-generational poverty because of their focus on education and health-care for children. On the other hand, they militate against structural change for women by entrenching their role as child-carers. Nor is it clear that a simple cash transfer is sufficient to achieve their stated aims of breaking the cycle of poverty. Research on CCTPs shows that although enrolment at school increases, education outcomes do not. This demonstrates that unless there is simultaneous proper investment in the quality of the service provided, CCTPs will not achieve their aims. There is always the risk that such programmes will be considered a substitute for proper investment by the State in universal provision of good quality health and education. The World Bank acknowledges that health and education provision are often dysfunctional. ${ }^{76}$ Aber and Rawlings conclude that "the introduction of CCTPs has not resolved longstanding issues of quality, efficiency and effectiveness within social sector ministries, across the myriad of often uncoordinated social assistance providers, and in often outdated and financially insolvent social insurance programs." ${ }^{77}$ As the Special Rapporteur points out, CCTP programmes might in fact be a disincentive to improve such services, since families are compelled to use them. ${ }^{78}$

\footnotetext{
${ }^{74}$ Standing, supra note 66 at 32.

${ }^{75}$ Ibid. at 33.

${ }^{76}$ A. Fiszbein, N. Schady and et al., supranote 71 at 24.

${ }^{77}$ Aber and Rawlings, supra note 70.

${ }^{78}$ Sepúlveda,supranote 66 at para 20.
} 
Equally seriously, as we have seen, claims that CCTPs may change gender power relations within the family do not have a sound empirical basis. To the contrary, far from being transformative, CCTPs might entrench existing gender roles. A truly transformative approach would be that signalled by CEDAW, which requires States to promote "a common responsibility of men and women in the upbringing and development of their children.”79

\section{Participation}

The participative dimension regards participants as entitled to have a voice in the design, delivery and monitoring of programmes. Participation can improve the effectiveness and sustainability of programmes through feedback from its users; and to garner social and political support for cash transfer programmes. ${ }^{80}$ However, as the Special Rapporteur stresses: 'Without fair and effective mechanisms that enable beneficiaries to actively participate, CСTPs are vulnerable to political manipulation. ${ }^{81}$ Molyneux cites evidence suggesting that, despite claims that its aim was to function as a way of exercising civil and political rights and a means to achieve full citizenship, participants were not given an active role in the design, management or evaluation of the Mexican Oportunidades programme.

Moreover, participation means more than just consultation. In the context of poor women, it is important to be sure that women's lack of voice in the family or community is taken into account. If there are already obstacles to participation for vulnerable groups, then it is easy for participation structures to give the impression of giving voice, while in practice reinforcing existing power structures. The Special Rapporteur suggests that, to compensate for asymmetries of power, participation should therefore include civil society organisations that can play a role in advocating the rights of beneficiaries, and not just beneficiaries themselves. ${ }^{82}$

The result of the evaluation is not necessarily to scrap CCTPs, but to redesign them with these issues in mind. One possibility is to provide the cash transfer without the condition, as in South Africa.

\footnotetext{
${ }^{79}$ Art 5(b) of CEDAW.

${ }^{80}$ Ibid. at 52.

${ }^{81}$ Sepúlveda, supra note 66 at para 51.

${ }^{82}$ Ibid. at 54.
} 
Unconditional cash transfers indeed score much better on the four - dimensional framework for women's substantive equality although here too they should not be seen as a substitute for proper investment in publicly available services such as health and education. Real substantive equality is most likely to be achieved, not through making women bear the burden of breaking the inter-generational cycle of poverty but through universal, free access to good quality State schools, health clinics, and other essential services.

\section{B. Let a woman fish for a day: Micro-credit and substantive equality}

A similar analysis could be done in relation to micro-credit or micro-financing, the private sector analogue of CCTPs. As is the case with CCTPs, micro-financing has focussed on women, on the assumption that women can be relied on to spend their assets on their children and household. Microcredit has also capitalised on communal self-help initiatives of poor women, such as 'thrift' groups through which women (but also men) help each other to save small amounts every month. This creates a credit pool from which individual members can draw in difficult times (for example, to pay for funerals), or which permits the group as a whole to benefit from the savings achievable through bulk buying groceries or purchasing common assets such as storage bins. ${ }^{83}$ Recognising the effectiveness of these groups in mobilising collective resources and ensuring repayment, banks, NGOs, governments and other agencies encouraged them to access credit from formal institutions. Parthasarathy shows, however, that the absorption capacity of the thrift group and its ability to manage resources of the thrift group gradually dropped out of the picture. Instead, the focus soon became the need for the institution to meet lending targets, often leading to over-lending. ${ }^{84}$ Microcredit in turn led to the development of microfinance, which offers other financial services such as micro-insurance, health risk coverage and housing credit benefits. Morduch notes that, in 2013, about three quarters of microfinance customers worldwide were women. In South Asia, nearly all were women. ${ }^{85}$ Putting microcredit under a

\footnotetext{
${ }^{83}$ S. Parthasarathy Fact and Fiction: Examining Microcredit/Microfinance from a Feminist Perspective, Association for Women's Rights in Development (2012) at 2.

${ }^{84}$ Ibid.

${ }^{85}$ J. Morduch, How Microfinance Really Works, Second Quarter, The Milken Institute Review (2013) 50-60 at 54.
} 
substantive gender equality lens allows us to evaluate the extent to which it can advance equality for women and whether and how it would need to be adjusted to do so.

\section{Redressing disadvantage}

Microcredit clearly enables access to cash to bridge short-term needs. But unlike cash transfers, or earned income, it carries with it the burden of repayment. Thus, such credit can only be seen as redressing disadvantage in any real sense if it can be used as capital to provide its own income earning opportunities or to empower women in other ways. There are many who have viewed it as the silver bullet to address poverty. Kofi Annan, previous Secretary-General of the UN, described microcredit as "an idea whose time has come” and Jonathan Morduch, then chair of the UN expert group on Poverty statistics declared that: "Microfinance stands as one of the most promising and cost-effective tools in the fight against global poverty." 86

However, the optimism of the earlier years has not been born out. A controlled study of the use of microcredit provided to women in a location in India found that there were no changes in the outcomes believed to be affected by microfinance, including women's empowerment, education and health. ${ }^{87}$ The results of the study led the authors to "revise downward the role of microcredit as primarily being an engine of escape from poverty through small business growth." ${ }^{88}$ A particularly important finding of this research is that capital is far more likely to be used to further larger businesses than to help jump start small business. ${ }^{89 ،}$ For everyone else, business profits do not increase, and on average microfinance does not help the businesses to grow in any significant way." ${ }^{90}$ Although microcredit did lead to an increase in the number of new businesses created, particularly by women, these marginal businesses were even smaller and less profitable than the average businesses in the area, which were

\footnotetext{
${ }^{86}$ The Emily Fund 'Microcredir Quotes'<http://www.doonething.org/quotes/microcredit-quotes htm> (accessed 7th July 20014).

${ }^{87}$ E. Duflo, A. Banerjee, R. Glennerster and C. Kinnan, The Miracle of Microfinance? Evidence from a Randomized Evaluation, National Bureau of Economic Research Working Paper No. 118950 (May 2013)

$<$ http://www.nber.org/papers/w18950> (accessed 8th July 2014) at 5.

${ }^{88} \mathrm{Ibid}$. at 26.

${ }^{89}$ Ibid.at 24.

${ }^{90}$ Ibid. at 26.
} 
already small and unprofitable. ${ }^{91}$ These small businesses tend not to employ others, or have capital assets, and so are fragile and highly dependent on the efforts of the individual woman. Yet, pregnancy and childcare make it inevitable that businesses run by women in their child-bearing years will be subject to frequent interruptions. Many female entrepreneurs are also especially vulnerable to violence, whether maliciously aimed at obstructing women entrepreneurs or as victims to street crime. ${ }^{92}$ Nor was there a positive impact on expenditure on food, health or education..$^{93}$

Research also shows that poor households are more likely to use the loans on purchases of durable goods for household use than on launching a business. What appear to be small enterprises using the opportunities provided by microcredit are instead instances of women entering the informal sector to earn money to pay back loans used on household durables. The Miracle of Microcredit study noted the high incidence of food businesses (tea/coffee stands, food vendors etc) in their study, and pointed out that these needed too little capital investment to warrant a household taking out a loan. This strongly suggested that instead the household was expanding its labour to pay back a loan taken out for other reasons. Indeed Morduch proposes that microcredit be rethought as a consumer loan rather than a business loan. ${ }^{94}$ Rather than being repaid out of the putative profits of new enterprises, such loans are repaid by a combination of earned income, self-employment income or other money, for example money saved from expenditure on "temptation goods". The concern here is that this is an extra burden on women's time, which is already highly constrained. Moreover, where such alternative incomeearning opportunities are not available, the increasing burden of debt risks plunging poor women into greater poverty. This is aggravated by the competition between micro lenders, giving borrowers the option of borrowing from one to repay another..$^{95}$ Thus, while there are some women who have benefited from the micro financing project, it does not score well on the redressing disadvantage dimension.

2. Addressing stigma stereotyping, prejudice, and violence

\footnotetext{
${ }^{91}$ Ibid.

${ }^{92}$ L.Scott, supra note 45.

${ }^{93}$ Ibid. at 27.

${ }^{94} \mathrm{~J}$. Morduch, supranote 94 at 58.

${ }^{95}$ Ibid. at 57.
} 
Central to the project of microcredit is the essentialist view of women as efficient managers of resources, and especially able to use limited resources for their families and communities. ${ }^{96}$ Bono’s slogan reflects this well: "Give a man a fish, he'll eat for a day. Give a woman microcredit, she, her husband, her children and her extended family will eat for a lifetime." ${ }^{97}$ Muhammed Yunus, the Bangladeshi economist who pioneered microcredit in that region, saw poor women as frustrated entrepreneurs. They had the ideas, knowledge and connections to run businesses: what they lacked was capital. ${ }^{98}$ This cements women into particular roles, while at the same time failing to dislodge existing stereotypes of women as child-bearers and carers on the one hand, and sexual objects on the other. This overlaying of stereotypes undercuts the potential of recognising women as genuine agents and good citizens of their communities.

In particular, far from addressing violence within and outside of the family, it can expose women to greater violence both because of their access to desired assets and the threat to traditional women's roles. Linda Scott puts it even more strongly:

The most potentially damaging gender issue for any intervention is violence. ...Beginning with the reports of increased domestic attacks against the early micro lending groups in Bangladesh, the patterned response of violence whenever women are given a helping hand toward economic autonomy has become a matter for constant vigilance. All economic interventions on behalf of women should consider the potential for violence: attacks are not ancillary to gender inequality, but the instrumental means by which systematic disadvantage is held in place. Violence is an implicit, if not explicit, presence in women's lives all over the world, but it is particularly likely to emerge when the local norms of feminine submission are threatened. ${ }^{99}$

\section{Structural change}

Instead of confronting structural obstacles to women's advancement, microcredit initiatives assume that women can solve the problems of poverty through their own entrepreneurship. This takes no account of structural constraints on women. Women entrepreneurs are still exposed to all the precariousness of the informal sector, including highly volatile markets, violence and absence of proper maternity and health and safety rights. As Parthasarathy puts it, “Despite clear evidence that the nature of women’s

\footnotetext{
${ }^{96}$ S. Parthasarathy, supranote 92 at 3.

${ }^{97}$ The Emily Fund, supra note 95.

${ }^{98} \mathrm{~J}$. Morduch, supranote 94 at 54.

${ }^{99}$ L. Scott, supra note 45.
} 
poverty lay in structural impediments, including patriarchy, racism and classism, in access to resources there remained a complete lack of engagement with the causes of poverty." ${ }^{100}$ Indeed, microcredit could be said to have relieved States of their obligations both to ensure decent work for all, and to provide the appropriate infrastructure of services, including health, education, protection from violence and social security, which are necessarily to genuinely achieve structural change. This is recognised in recent research. Thus according to the Miracle of Microfinance study, the fact that businesses operated by women tend in general to be less profitable is due to the social constraints on what women can do and how much time they have to devote to it. ${ }^{101}$ Nor has microcredit necessarily changed the balance of power within the home. Research shows that there are many occasions in which women borrow money at the behest of their husbands or other male figures.

\section{Voice and participation}

As we have seen, the highly participatory nature of thrift groups, which were the basis of early microlending, has been undermined by the shift in lenders' approach, from a demand-based tool, to a supplybased financial product. “In this way, group members’ needs and demands are no longer the determining entity and members, in effect, become faceless clients." ${ }^{102}$ This might have been counteracted had microcredit turned out to give women greater voice in decision-making within the family. However, the Miracle of Microfinancing research has found the opposite. Women in areas in which microcredit was available were no more likely to be the primary decision-makers regarding household spending, investment, savings or education. This was even true regarding what food to purchase. Moreover, women in households were no more likely to report being the person to decide to take the loan. ${ }^{103}$

\section{CONCLUSION}

\footnotetext{
${ }^{100}$ S. Parthasarathy, supra note 92 at 3.

${ }^{101}$ E. Duflo et al., supra note 96 at 25.

${ }^{102}$ Ibid. at 2 .

${ }^{103} \mathrm{Ibid}$. at 27.
} 
Muhammad Yunus has declared that a key aspect of his vision of the future is "to make credit a human right so that each individual human being will have the opportunity to take loans and implement his or her ideas so that self-exploration becomes possible.” ${ }^{104}$ This paper has taken a different view of the role of human rights in addressing women and poverty. Human rights are more than market-based freedoms. A human rights based approach to poverty requires the State and other powerful agents to address the real constraints that impede the ability of people in poverty to genuinely exercise their rights. Moreover, the policies put in place to fulfil these duties should advance women's right to substantive equality, understood in the multi-dimensional sense proposed here. In other words, such policies should address specifically gender-based disadvantage, including mal-distribution of power as well as resources; they should avoid gendered stigmatic consequences for women and instead advance dignity and respect; they should work towards structural change rather than cementing existing stereotypical roles for women; and they should facilitate participation and voice. At the same time, a gender perspective should not obscure the reality of poverty for both men and women. The answer is not necessarily to shift responsibility to women, but to universalise the burden through State provision of services. Real substantive equality is most likely to be achieved, not through making women bear the burden of breaking the inter-generational cycle of poverty but through universal, free access to good quality State schools, health clinics, and other essential services.

104 The Emily Fund, supra note 95. 
